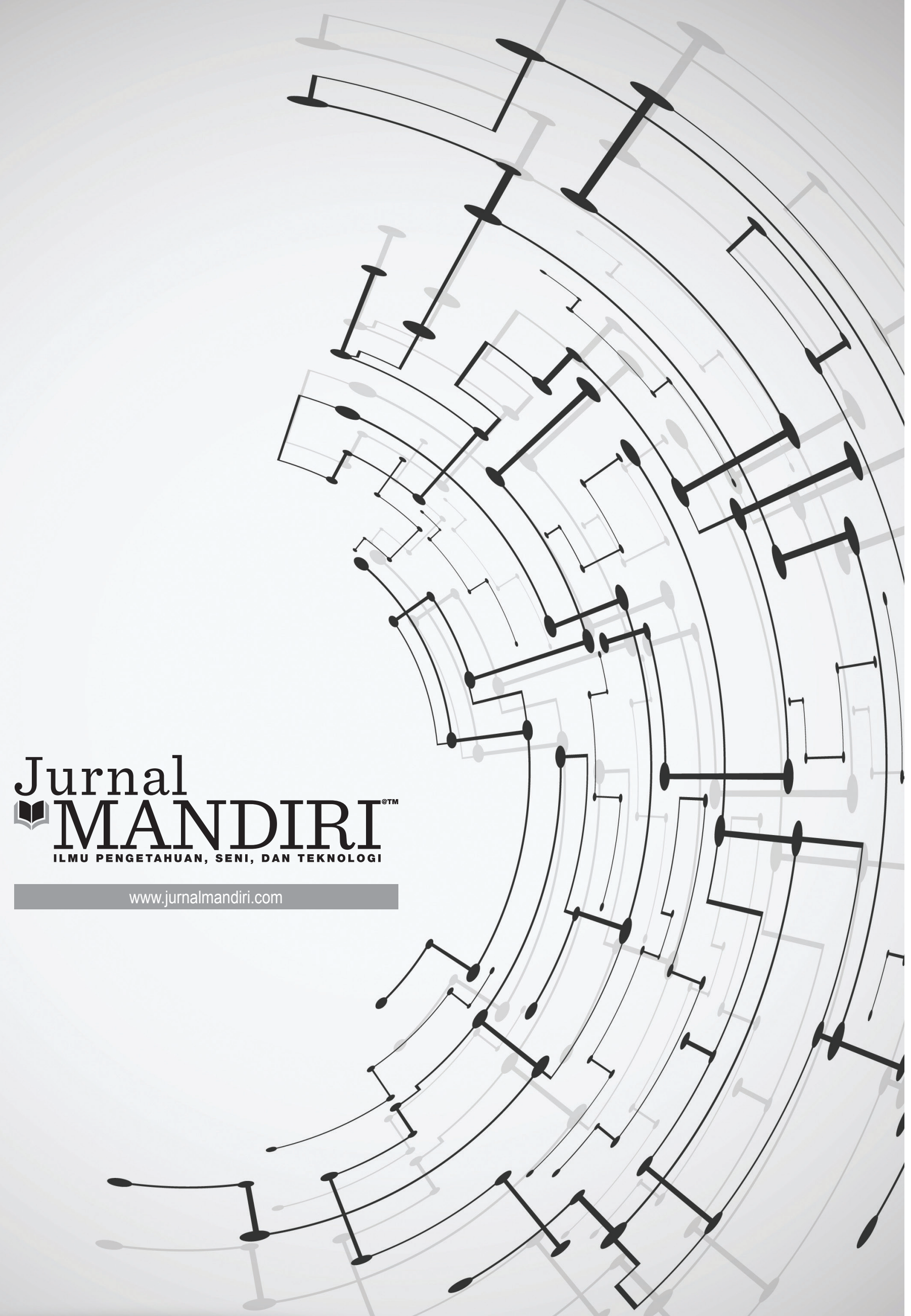


ISSN : 2580-3220, E-ISSN : 2580-4588

J. Mandiri., Vol. 1, No. 2, Desember 2017 (274 - 288)

(C2017 Lembaga Kajian Demokrasi

dan Pemberdayaan Masyarakat (LKD-PM)

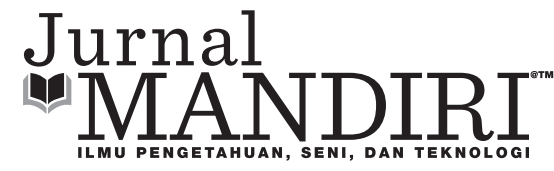

\title{
PENGARUH HARGA TERHADAP MINAT BELI (STUDI KASUS PADA PT ASURANSI JIWA RECAPITAL DI JAKARTA)
}

\author{
Fauziah Septiani \\ Universitas Pamulang \\ fauziahseptiani0209@gmail.com
}

\begin{abstract}
ABSTRAK
Penelitian ini bertujuan untuk mengetahui pengaruh harga terhadap minat beli pada PT Asuransi Jiwa Recapital di Jakarta. Metode yang digunakan dalam penelitian ini adalah menggunakan metode explanatory research dan pengujian hipotesis. Dengan teknik survei, menyebar kuesioner dengan skala Likert. Teknik penentuan sampel dengan proporsional random sampling digunakan rumus Slovin diperoleh 100 responden. Teknik analisis data yang digunakan Analisis deskriptif dan Analisis statistik inferesial yaitu: 1. Uji Validitas dan Reliabilitas, 2. Analisis Regresi Linier Sederhana, 3. Analisis Koefisien Korelasi, 4. Analisis Koefisien Determinasi (R2), 5. Pengujian Hipotesis dengan Uji t. Hasil pengujian dan analisisnya adalah terdapat pengaruh positif dan signifikan antara harga terhadap minat beli pada PT Asuransi Jiwa Recapital di Jakarta dengan kontribusi pengaruh sebesar 31,6\% dan nilai thitung sebesar 3,489 dengan signifikansi t sebesar 0,001.
\end{abstract}

Kata Kunci : Harga, Minat Beli

\section{PENDAHULUAN}

\section{Latar Belakang}

Perkembangan jaman yang semakin maju, sehingga persaingan tidak terhindarkan lagi dalam dunia bisnis atau industri seperti halnya persaingan di dalam dunia bisnis yang menyebabkan kegiatan manufaktur atau non manufaktur (jasa) sangat membutuhkan kemampuan baru agar perusahaan dapat berhasil secara kompetitif dengan berbagai upaya untuk memenuhi kebutuhan konsumen dan peningkatan pelayanan.

Industri jasa pada saat ini merupakan sektor ekonomi yang sangat besar dan pertumbuhannya pun sangat pesat. Pertumbuhan tersebut selain diakibatkan oleh pertumbuhan jenis jasa yang sudah ada sebelumnya, juga disebabkan oleh munculnya jenis jasa baru, sebagai akibat dari tuntutan dan perkembangan zaman. Dipandang dari segi konteks globalisasi, pesatnya pertumbuhan bisnis jasa antar negara ditandai dengan meningkatnya intensitas pemasaran lintas negara serta terjadinya aliansi berbagai penyedia jasa di dunia.

Membangun dan mengembangkan asuransi seringkali dipandang sebelah mata oleh kalangan masyarakat, ini terjadi karena belum sadarnya masyarakat akan pentingnya kebutuhan asuransi di masa sekarang dan masa yang akan datang. Pada saat ini perusahaan asuransi 
sedang berusaha memperkenalkan produk kepada masyarakat dan memberikan kualitas pelayanan yang baik untuk menarik konsumen, maka dari itu kunci sukses bagii perusahaan jasa adalah pelayanan jasa yang baik dan tersediannya produk jasa yang dibutuhkan pelanggan juga peningkatan kualitas pelayanan baik.

Salah satu produk jasa terkemuka dalam bidang asuransi adalah asuransi jiwa, dimana asuransi jiwa merupakan salah satu hal yang sangat penting karena sebagai salah satu instrumen yang dapat digunakan untuk meminimalisasi resiko-resiko yang mungkin terjadi dalam kehidupan, dalam hal ini dikhususkan resiko yang bersifat finansial yang dapat membahayakan kesejahteraan keluarga akibat terjadinya musibah sakit, kecelakaan atau kematian.

Mekanisme perlindungan yang diberikan oleh pihak perusahaan asuransi sangat dibutuhkan, baik dalam dunia bisnis yang penuh dengan resiko dimana recara rasional para pelaku bisnis akan mempertimbangkan usaha untuk mengurangi resiko yang dihadapi. Salah satu faktor yang ikut menentukan tercapai atau tidaknya tujuan perusahaan adalah strategi perusahaan dalam memberikan harga. Harga dianggap sebagai salah satu faktor yang menentukan bagi perusahaan, namun setiap perusahaan hendaknya mempertimbangkan secara matang setiap keputusan dalam masalah harga.

Perusahaan asuransi dalam undang-undang Nomor 2 Tahun 1992, dirumuskan definisi asuransi yang lebih lengkap jika dibandingkan dengan rumusan yang terdapat dalam Pasal 246 KUHD. Menurut ketentuan Pasal 1 angka (1) Undang-undang Nomor 2 Tahun 1992: “ Asuransi atau pertanggungan adalah Perjanjian antara 2 (dua) pihak atau lebih, dengan mana pihak penanggung mengikatkan diri kepada tertanggung dengan menerima premi asuransi, untuk memberikan penggantian kepada tertanggung karena kerugian kerusakan atau kehilangan keuntungan yang diharapkan atau tanggung jawab hukum kepada pihak ketiga yang mungkin akan diderita tertanggung, yang timbul dan suatu peristiwa tidak pasti atau untuk memberikan suatu pembayaran yang didasarkan atas meninggal atau hidupnya seseorang dipertanggungkan.

Dalam KUHD asuransi jiwa diatur dalam Buku 1 Bab X pasal 302. pasal 308 KUHD. Jadi hanya 7 (tujuh) pasa. Akan tetapi tidak 1 (satu) pasalpun yang memuat rumusan definisi asuransi jiwa. Dengan demikian, sudah tepat jlka definisi asuransi dalam Pasal 1 angka (1) Undang-Undang Nomor 2 Tahun 1992 dijadikan titik totak pembahasan dan ini ada hubungannya dengan ketentuan Pasal 302 dan Pasal 303 KUHD yang membolehkan orang mengasuransikan jiwanya.

Di Indonesia perkembangan asuransi semakin pesat, hal tersebut bisa terlihat dari banyaknya perusahaan asuransi yang berlomba memperkenalkan produk asuransi kepada masyarakat. Di sini perusahaan asuransi tersebut harus mampu bersaing dengan perusahaan asuransi lainnya, dalam persaingan penjualan produk asuransi yang harus diperhatikan untuk memenuhi kebutuhan para konsumen adalah dari sisi harga yang ditawarkan, promosi yang dilakukan seperti apa, produk yang dijual dan pelayanan kepada pelanggan juga harus diperhatikan.

Perusahaan Asuransi saat ini sedang membangun bisnis yang sangat menjanjikan, terlebih sekarang masyarakat sudah mulai sadar dengan pentingnya asuransi. Masyarakat sekarang sudah mulai sadar dengan adanya asuransi jiwa, asuransi general itu memanglah sangat penting untuk kehidupan sekarang. Terlihat sekarang banyak sekali perusahaan-perusahaan asuransi yang berlomba mempromosikan produknya. Harga yang ditawarkan juga sangat menarik masyarakat agar menggunakan asuransi tersebut.

Bisnis asuransi saat ini memiliki pertumbuhan yang sangat baik. Namun dengan demikian, oleh karena semakin tinggi nya persaingan asuransi yang ada apabila perusahaan tersebut 
melakukan sedikit kesalahan pada harga, produk dan pelayanan terhadap masyarakan disini akan menyebabkan terjadinya kelambatan pada bisnis tersebut.

Kendala yang dihadapi oleh PT Asuransi Jiwa Recapital saat ini adalah harga yang masih belum bisa bersaing oleh kompetitor lain, disini penulis akan menjelaskan terlebih dahulu harga yang terdapat pada asuransi jiwa (kesehatan) disini adalah harga rata-rata dari permintaan konsumen.

Maka dari hasil prariset yang penulis lakukan banyak ditemukan kendala-kendala yang muncul diantaranya memperlihatkan bahwa kebijakan tingkat harga yang diambil oleh perusahaan pada setiap tahunnya mengalami perkembangan yang berfluktuatif. Tentu saja kebijakan tersebut memiliki alasan dan tujuan, akan tetapi jika di compare dengan jumlah pelanggan yang dapat dicapai maka tidak selalu penurunan harga diiringi dengan kenaikan jumlah pelanggan. Sedangkan menurut Phililip Kotler dan Amstrong, (2012) berpendapat "Harga adalah sejumlah uang yang dibebankan atas suatu produk atau jasa, atau jumlah dari suatu yang ditukar konsumen atas manfaat-manfaat karena memiliki atau menggunakan produk atau jasa".

Semakin tingginya persaingan bisnis asuransi semakin tinggi minat beli yang diinginkan oleh konsumen seperti menurut Kinnear dan Taylor (2011), "Minat beli merupakan bagian dari komponen perilaku konsumen dalam sikap mengkonsumsi, kecenderungan responden untuk bertindak sebelum keputusan membeli benar-benar dilaksanakan".

Tingginya tingkat persaingan direfleksikan dengan makin sensitifnya tuntutan pelanggan terhadap faktor yang dapat memberikan keyakinan seseorang dalam menentukan membeli produk ataupun jasa.

Manajemen PT Asuransi Jiwa Recapital telah melakukan berbagai upaya untuk meningkatkan minat beli pelanggan, seperti disediakannya layanan call center keluhan pelang- gan 24 jam, mempermudah pelayanan pelanggan dalam pembayaran, dan proses claim.

Banyaknya pilihan produk dan jasa yang tersedia membuat konsumen lebih cenderung menjatuhkan pilihan sesuai dengan persepsi mereka terhadap jenis layanan tertentu yang menjadi favorit mereka. Perusahaan berlombalomba memperluas pangsa pasarnya, mencoba menarik pelanggan dengan cara mempengaruhi sikap konsumen agar bersedia membeli produk-produk mereka. Asuransi jiwa yang terkait dengan finansial adalah salah satu alternatif masyarakat dalam menjamin kebutuhannya baik segi kesehatan maupun lainnya.

Mengingat bahwa harga merupakan salah satu faktor yang dapat memberikan keyakinan seseorang untuk memiliki kemauan untuk membeli kembali pada PT Asuransi Jiwa Recapital Jakarta. Maka penulis tertarik untuk melakukan penelitian lebih dalam dengan judul : "Pengaruh Harga Terhadap Minat Beli" (Studi Kasus Pada PT Asuransi Jiwa Recapital Di Jakarta).

\section{PEMBATASAN MASALAH}

Dengan keterbatasan peneliti serta agar penelitian memiliki kajian dan analisis yang terfokus dan mendalam, maka dalam kegiatan ini penelitian hanya akan melakukan kajian dan analisis pada kondisi harga terutama pengaruhnya terhadap minat beli pada PT Asuransi Jiwa Recapital.

\section{PERUMUSAN MASALAH}

Berdasarkan identifikasi dan pembatasan masalah di atas, maka untuk mencegah terjadinya kerancuan dalam pembahasan, perlu penulis berikan suatu perumusan masalah sebagai berikut :

1. Bagaimana kondisi harga pada PT Asuransi Jiwa Recapital di Jakarta?

2. Bagaimana kondisi minat beli pada PT Asuransi Jiwa Recapital di Jakarta?

3. Apakah terdapat pengaruh antara harga terhadap minat beli pada PT Asuransi Jiwa Recapital di Jakarta? 


\section{TUJUAN PENELITIAN}

Tujuan penelitian ini adalah :

1. Untuk mengetahui kondisi harga pada PT Asuransi Jiwa Recapital di Jakarta.

2. Untuk mengetahui kondisi minat beli pada PT Asuransi Jiwa Recapital di Jakarta.

3. Untuk mengetahui pengaruh antara harga terhadap minat beli pada PT Asuransi Jiwa Recapital di Jakarta.

\section{TINJAUAN TEORITIK}

\section{Manajemen}

Manajemen banyak dikemukakan oleh para ahli dengan berbagai definisi yang mempunyai ragam penekanan yang berbeda meskipun secara keseluruhan definisi-definisi tersebut masih saling berkaitan.

Menurut Hasibuan (2013) "Manajemen adalah ilmu dan seni mengatur proses pemanfaatan sumber daya manusia dan sumbersumber lainnya secara efektif untuk mencapai suatu tujuan tertentu". Menurut Appley dan Oey Liang Lee (2010) manajemen adalah seni dan ilmu, dalam manajemen terdapat strategi memanfaatkan tenaga dan pikiran orang lain untuk melaksanakan suatu aktifitas yang diarahkan pada pencapaian tujuan yang telah ditentukan sebelumnya. Dalam manajemen terdapat teknik-teknik yang kaya dengan nilai-nilai estetika kepemimpinan dalam mengarahkan, memengaruhi, mengawasi, mengorganisasikan semua komponen yang saling menunjang untuk tercapainya tujuan yang dimaksudkan.

Sedangkan menurut G.R. Terry (2010) menjelaskan bahwa manajemen merupakan suatu proses khas yang terdiri atas tindakan-tindakan perencanaan, pengorganisasian, penggerakan, dan pengendalian untuk menentukan serta mencapai tujuan melalui pemanfaatan sumber daya manusia dan sumber daya lainnya.

Dari beberapa pendapat tersebut di atas penulis menarik kesimpulan bahwa manajemen adalah proses perencanaan, pengorganisasian, pelaksanaan dan pengawasan kegiatan-kegiat- an dalam suatu organisasi yang sudah direncanakan dengan efisien untuk mencapai tujuan yang telah ditetapkan oleh organisasi tersebut.

\section{Manajemen Pemasaran}

Manajemen Pemasaran biasanya mencakup perencanaan strategi dari seluruh usaha organisasi/ perusahaan. Manajemen pemasaran dapat terjadi disebuah organisasi dalam hubungan dengan pasarnya dan juga untuk mempengaruhi tingkat, jangkauan, waktu dan komposisi permintaan dalam suatu cara sehingga membentuk organisasi untuk mencapai sasarannya.

Menurut Sofjan Assauri (2013) Manajemen Pemasaran adalah kegiatan menganalisis, merencanakan, melaksanakan dan mengendalikan program-program yang disusun dalam pembentukan, pembangunan, dan pemeliharaan keuntungan dari pertukaran/ transaksi melalui sasaran pasar dengan harapan untuk mencapai tujuan organisasi (perusahaan) dalam jangka panjang.

Menurut Kotler (2012) pengertian manajemen pemasaran adalah sebagai berikut: Manajemen Pemasaran adalah penganalisaan, pelaksanaan, dan pengawasan, program-program yang ditujukan utuk mengadakan pertukaran dengan pasar yang dituju dengan maksud untuk mencapai tujuan organisasi. Hal ini sangat tergantung pada penawaran organisasi dalam memenuhi kebutuhan dan keinginan pasar tersebut serta menentukan harga, mengadakan komunikasi, dan distribusi yang efektif untuk memberitahu, mendorong serta melayani pasar.

Pengertian manajemen pemasaran menurut Buchori dan Djaslim (2010) adalah proses perencanaan dan pelaksanaan konsepsi, penetapan harga, promosi dan distribusi gagasan, barang, dan jasa, untuk menghasilkan pertukaran yang memuaskan individu dan memenuhi tujuan organisasi. Manajemen pemasaran dapat terjadi disebuah organisasi dalam hubungan dengan pasarnya dan juga untuk mempengaruhi tingkat, jangkauan, waktu dan komposisi per- 
mintaan dalam suatu cara sehingga membentuk organisasi untuk mencapai sasarannya.

\section{Pemasaran.}

Pemasaran merupakan sebuah konsep kunci keberhasilan suatu bisnis dimana pemasaran dengan memperhatikan keinginan dan pemenuhan kebutuhan pelanggan untuk tercapainya target penjualan yang ditetapkan sehingga memberi dampak positif bagi perkembangan usaha suatu perusahaan di tengah persaingan bisnis yang begitu ketat dewasa ini. Pemahaman pemasaran bagi pemasar sangat penting untuk pengenalan kebutuhan dan keinginan pelanggan, penentuan pasar sasaran mana yang dapat dilayani, serta merancang produk dan program yang tepat dalam melayani pasar sehingga dapat mengoptimalkan penjualan.

Menurut Kotler dan Keller (2012) mendefinisikan pemasaran adalah suatu proses sosial dan manajerial yang membuat individu maupun kelompok memperoleh apa yang mereka berikan dan yang mereka inginkan dengan menciptakan, menawarkan dan secara bebas mempertukarkan produk dan jasa yang bernilai dengan pihak lain.

Sedangkan menurut William J. Stanton (2010) menyatakan pemasaran adalah sistem keseluruhan dari kegiatan usaha/bisnis yang ditujukan untuk merencanakan, menentukan harga, mempromosikan dan mendistribusikan barang dan jasa yang dapat memuaskan kebutuhan pembeli yang ada maupun pembeli potensial.

Karena asuransi yang dijual adalah jasa maka sedikit akan kami sampaikan menurut Payne yang dikutif oleh Ratih Hurriyati (2010) pemasaran jasa merupakan suatu proses mempersepsikan, memahami, menstimulasi dan memenuhi kebutuhan pasar sasaran yang dipilih secara khusus dengan menyalurkan sumbersumber sebuah organisasi untuk memenuhi kebutuhan tersebut. Dengan demikian, manajemen pemasaran jasa merupakan proses penyelarasan sumber-sumber sebuah organisasi terhadap kebutuhan pasar.
Pemasaran memberi perhatian pada hubungan timbal balik yang dinamis antara produk dan jasa perusahaan, keinginan dan kebutuhan pelanggan serta kegiatan-kegiatan para pesaing. Pemasaran dalam suatu perusahaan memegang peranan yang sangat penting, karena merupakan salah satu kegiatan yang dilakukan untuk mempertahankan kelangsungan hidup operasional perusahaan, melakukan perkembangan terhadap perusahaan dan untuk pencapaian tujuan perusahaan dalam memperoleh laba.

\section{Asuransi}

Menurut Pasal 246 Kitab Undang-undang Hukum Dagang (KUHD) Republik Indonesia: "Asuransi atau pertanggungan adalah suatu perjanjian, dengan mana seorang penanggung mengikatkan diri pada tertanggung dengan menerima suatu premi, untuk memberikan penggantian kepadanya karena suatu kerugian, kerusakan atau kehilangan keuntungan yang diharapkan, yang mungkin akan dideritanya karena suatu peristiwa yang tak tertentu".

Menurut Prof. Mehr dan Cammack yang dikutip oleh Zian Faradois (2013): "Asuransi merupakan suatu alat 12 untuk mengurangi resiko keuangan, dengan cara pengumpulan unit-unit exposure dalam jumlah yang memadai, untuk membuat agar kerugian individu dapat diperkirakan. Kemudian kerugian yang dapat diramalkan itu dipikul merata oleh mereka yang tergabung”. Sedangkan asuransi menurut Zian Faradois (2013) adalah suatu sistem atau tindakan untuk melimpahkan, mengalihkan dan mentransfer risiko yang ditanggung kepada pihak lain dengan syarat melakukan pembayaran premi dalam rentan waktu tertentu secara teratur sebagai ganti polis yang menjamin perlindungan terhadap risiko yang memungkinkan terjadi di masa depan seiring dengan ketidakpastian itu sendiri.

Ada beberapa manfaat asuransi yang bisa kita ambil seperti bisa sebagai investasi dan tabungan, bisa membantu mengatur keuangan kita, membantu meminimalkan kerugian dan 
bisa sedikit memberikan ketenangan untuk kita. Asuransi juga dibagi kedalam beberapa jenis yaitu asuransi jiwa, asuransi kesehatan, asuransi kendaraan, asuransi kepemilikan rumah atau property, asuransi pendidikan, asuransi bisnis dan asuransi kredit.

\section{Harga}

Harga merupakan elemen yang penting dalam pemasaran karena menyangkut nilai sebuah produk. Tingkat harga, keringanan harga dan syarat dalam melakukan pembayaran merupakan pengurangan dari harga yang ada. Pengurangan ini dapat berbentuk tunai atau berupa konsesi yang lain.

Menurut Bashu Swastha (2010), "Harga adalah jumlah uang (ditambah beberapa barang kalau mungkin) yang dibutuhkan untuk mendapatkan sejumlah kombinasi dari barang beserta pelayanannya".

Menurut Kotler dan Armstrong (2010) Harga adalah sejumlah uang yang dibebankan atas suatu produk atau jasa, atau jumlah dari nilai yang ditukar konsumen atas manfaatmanfaat karena memiliki atau menggunakan produk atau jasa tersebut.

Harga menurut Samsul Ramli (2013) adalah nilai relatif dari produk dan bukan indikator pasti dalam menunjukan besarnya sumber daya yang diperlukan dalam menghasikan produk.

Menurut Bashu Swasta (2010) menjelaskan ada beberapa dimensi yang dapat digunakan untuk mengukur harga, diantaranya adalah:
a. Tingkat harga
b. Potongan harga
c. Syarat pembayaran

\section{Minat Beli}

Menurut Mowen (2011) berpendapat "Minat beli adalah sesuatu diperoleh dari proses belajar dan proses pemikiran yang yang membentuk suatu persepsi”. Minat beli ini menciptakan suatu motivasi yang terus terekam dalam benaknya dan menjadi suatu keinginan yang sangat kuat yang pada akhirnya ketika seorang konsumen harus memenuhi kebutuhannya akan mengaktualisasikan apa yang ada di dalam benaknya itu.

Kinnear dan Taylor (2011), "Minat beli merupakan bagian dari komponen perilaku konsumen dalam sikap mengkonsumsi, kecenderungan responden untuk bertindak sebelum keputusan membeli benar-benar dilaksanakan".

Menurut Philip Kotler (2012:34) berpendapat "Faktor utama yang mempengaruhi minat beli dan perilaku pembelian terdiri atas beberapa faktor penentu", Faktor tersebut meliputi:

a. Faktor kebudayaan yang terdiri dari : kultur, subkultur, kelas sosial.

b. Faktor sosial yang terdiri dari: kelompok, referensi keluarga, peran dan status.

c. Faktor pribadi yang terdiri dari: usia dan tahap daur hidup, jabatan, keadaan ekonomi, gaya hidup, pepribadian dan konsep diri.

d. Faktor psikologis yang terdiri dari: motivasi, persepsi, belajar, kepercayaan dan sikap. Menurut Ferdinand (2011), minat beli dapat diidentifikasi melalui indikator-indikator:

a. Minat transaksional, yaitu kecenderungan seseorang untuk membeli produk.

b. Minat refrensial, yaitu kecenderungan seseorang untuk mereferensikan produk kepada orang lain.

c. Minat preferensial, yaitu minat yang menggambarkan perilaku seseorang yang memiliki prefrensi utama pada produk tersebut. Preferensi ini hanya dapat diganti jika terjadi sesuatu dengan produk prefrensinya.

d. Minta eksploratif, minan ini menggambarkan perilaku seseorang yang selalu mencari informasi mengenai produk yang diminatinya dan mencari informasi untuk mendukung sifat-sifat positif dari produk tersebut.

\section{HIPOTESIS PENELITIAN}

Pengujian hipotesis dimaksudkan sebagai cara untuk menentukan apakah suatu hipote- 
sis sebaiknya diterima atau ditolak. Hipotesis menurut Sugiyono (2012) adalah pernyataan singkat yang merupakan jawaban sementara terhadap masalah yang diteliti serta masih perlu diuji kebenarannya". Karena sifatnya masih sementara, maka perlu dibuktikan kebenarannya melalui data empirik yang terkumpul.

Adapun Hipotesis yang penulis ajukan adalah sebagai berikut:

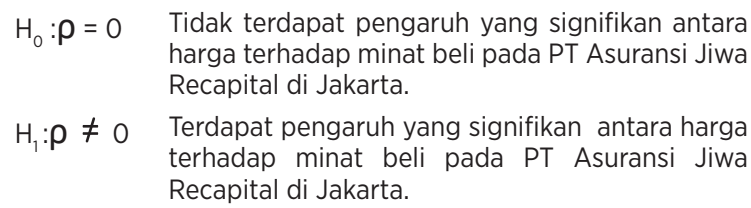
harga terhadap minat beli pada PT Asuransi Jiwa Recapital di Jakarta.

$\mathrm{H}_{1}: \rho \neq 0 \quad$ Terdapat pengaruh yang signifikan antara harga terhadap minat beli pada PT Asuransi Jiwa Recapital di Jakarta.

\section{METODOLOGI PENELITIAN TEMPAT DAN WAKTU PENELITIAN}

Penulis mengadakan penelitian pada PT Asuransi Jiwa Recapital dengan alamat kantor pusat Recapital Building Jln. Adityawarman Kav.55, Kebayoran Baru, Jakarta Selatan.

\section{POPULASI DAN SAMPEL}

\section{Populasi}

Populasi penelitian merupakan sekumpulan objek yang ditentukan melalui suatu kriteria tertentu yang akan dikategorikan ke dalam objek tersebut bisa termasuk orang, dokumen atau catatan yang dipandang sebagai objek penelitian. Menurut Sugiyono (2014) mendefinisikan "Populasi adalah jumlah wilayah generalisasi yang terdiri atas obyek atau subyek yang mempunyai kualitas dan karakteristik yang ditetapkan oleh peneliti dan kemudian ditarik kesimpulannya”. Sedangkan menurut Jonathan Sarwono (2012), "Populasi merupakan kesatuan yang mempunyai karakteristik yang sama dimana sampel akan kita tarik". Menurut Suharsimi Arikunto (2010), "Populasi adalah keseluruhan subjek penelitian".

Adapun populasi dalam penelitian ini adalah pelanggan perusahaan yang melakukan order pembelian pada PT Asuransi Jiwa Recapital di Jakarta pada setiap bulannya.

\section{Sampel}

Dalam pengambilan sampel dapat menggunakan sampling jenuh dimana menurut Sugiyono (2014) berpendapat "Sampling jenuh adalah teknik penentuan sampel bila semua anggota populasi digunakan sebagai sampel”. Istilah lain sampel jenuh adalah sensus, dimana anggota populasi di jadikan sebagai sampel. Teknik yang digunakan dalam penarikan sampel menggunakan teknik proporsional random sampling, dimana pemilihan sampel dilakukan secara acak sederhana secara proporsional dengan cara dihitung proporsionalnya mengingat pelanggan tersebar diseluruh Indonesia dengan karakteristik dan jumlah yang berbedabeda pada setiap wilayahnya, sehingga peneliti menganggap perlu dilakukan melakukan penyebaran kuesioner secara proporsional yang dianggap cukup mewakili kebutuhan penelitian ini. Jumlah sampel yang diambil dalam penelitian ini ditentukan dengan rumus Slovin. Jumlah responden yang dijadikan sampel sebanyak 100 responden yang mewakili perusahaannya.

\section{VARIABEL PENELITIAN}

Dalam penelitian ini terdapat dua variabel, yaitu variabel independen dan variabel dependen, yaitu:

1. Variabel bebas (independent variable) yang dalam hubungannya dengan variabel lain bertindak sebagai penyebab atau yang mempengaruhi variabel dependen. Pada penelitian ini sebagai variabel independen yakni harga. Variabel independen sering disebut sebagai predictor yang dilambangkan dengan X.

2. Variabel terikat (dependent variable) Variabel yang tergantung dengan variabel lain, atau variabel yang dapat dipengaruhi oleh variabel lain. Sering disebut variabel respon di mana dalam penelitian ini adalah minat beli yang dilambangkan dengan Y. 


\section{DEFINISI OPERASIONAL VARIABEL}

Pengertian operasional variabel ini kemudian diuraikan menjadi indikator empiris yang meliputi :

1. Harga (X)

Variabel ini diukur melalui indikator : Tingkat Harga, Potongan Harga dan Syarat Pembayaran.

2. Minat Beli (Y)

Variabel ini diukur melalui indikator : Minat Transaksional, Minat Refrensial, Minat Preferensional dan Minat Eksploratif.

\section{METODE PENGUMPULAN DATA}

\section{Kuesioner}

Angket merupakan sejumlah pertanyaan yang diajukan kepada responden secara tertulis. Daftar pertanyaan ditujukan pada responden terutama yang berkaitan dengan masalah yang akan diteliti dan dijawab dengan jawaban yang tersedia oleh responden. Menurut Sugiyono (2014) "Kuesioner merupakan tehnik pengumpulan data yang efisien apabila peneliti tahu dengan siapa variabel akan diukur dan tahu apa yang bisa diharapkan dari responden".

Dalam penelitian ini untuk mendapatkan data primer kuantitatif, penulis menghubungi responden yaitu pelanggan yang merupakan pelanggan yang secara rutin membeli produk di PT Asuransi Jiwa Recapital Jakarta.

\section{Wawancara.}

Untuk memperoleh data yang dapat diuji kebenaran dan sesuai dengan masalah yang diteliti secara lengkap, dengan menggunakan metode interview, yaitu metode pengumpulan data dengan melakukan tanya jawab langsung dengan pihak yang terkait. Menurut Sugiyono (2014) "Wawancara merupakan metode yang digunakan untuk memperoleh informasi secara langsung, mendalam, tidak terstruktur, dan individual"

Dalam penelitian ini untuk mendapatkan data primer kualitatif dengan metode wawancara, penulis datang ke kantor PT Asuransi Jiwa Recapital Jakarta untuk melakukan studi pen- dahuluan dengan teknik wawancara langsung dengan pihak yang berkompeten dalam perusahaan, mengenai obyek yang diteliti.

\section{Studi Pustaka.}

Merupakan elemen yang sangat penting dalam penelitian studi deskriptif karena tanpa adanya literature pendukung, maka penelitian akan mengalami kesulitan dan hambatan untuk memperoleh data, baik data yang bersifat teoritis maupun praktis.

Menurut Sugiyono (2014) "Studi kepustakaan berkaitan dengan kajian teoritis dan referensi lain yang berkaitan dengan nilai, budaya dan norma yang berkembang pada situasi sosial yang diteliti, selain itu studi kepustakaan sangat penting dalam melakukan penelitian, hal ini dikarenakan penelitian tidak akan lepas dari literatur-literatur ilmiah".

Untuk medapatkan data sekunder penulis melakukan dengan cara penelaahan terhadap literature-literature berupa buku-buku kuliah dan data yang diperoleh dalam bentuk yang sudah jadi, sudah diolah oleh pihak lain biasanya dalam bentuk publikasi serta bahan-bahan yang berhubungan dengan masalah yang berkaitan dengan penelitian ini.

\section{METODE ANALISIS DATA}

Metode analisis data yang digunakan dalam penelitan ini adalah:

\section{Uji Validitas}

Untuk mengolah uji validitas penulis menggunakan korelasi Product Moment yaitu dengan mengkorelasikan skor item dengan skor total sehingga diperoleh nilai rhitung kemudian dibandingkan dengan rtabel. Jika nilai rhitung lebih besar dari rtabel dan nilai $r$ positif, maka butir pernyataan dikatakan valid. Begitu juga sebaliknya, jika rhitung lebih kecil atau kurang dari rtable, maka data tersebut tidak valid Nilai rtabel untuk 100 responden dengan taraf kesalahan 5\% sebesar nilai $r$ tabel nya adalah sebesar 0,197. 


\section{Uji Reliabilitas}

Model analisis uji reliabiltas yang digunakan dalam penelitian ini adalah model $\mathrm{Al}$ pha Cronbach.

Menurut Arief (2009) untuk menentukan reliabel tidaknya sebuah instrumen dilakukan dengan cara membandingkan antara nilai rAlpha (Alpha Cronbach) dengan rtable yang sudah di ketahui pada uji validitas. Jika rAlpha positif dan lebih besar dari rtable maka instrumen tersebut dinyatakan handal (reliable). Sebaliknya jika rAlpha negatif atau rAlpha kurang dari rtable, maka instrumen tersebut dinyatakan tidak handal (not reliable).

\section{Uji Hipotesis (Uji t)}

Uji t digunakan untuk menguji signifikansi variasi hubungan antara variabel $\mathrm{X}$ dan $\mathrm{Y}$, dalam hal penelitian ini apakah variabel harga benar-benar berpengaruh terhadap variabel minat beli.

\section{Koefisien Determinasi}

Analisis koefiisien determinasi dimaksudkan untuk mengetahui besarnya pengaruh antara variabel independen terhadap variabel dependen. Menurut Andi Supangat (2008:350) "Koefisien determinasi merupakan besaran untuk menunjukkan tingkat kekuatan hubungan antara dua variabel atau lebih dalalm bentuk persen"

Dalam penelitian ini untuk mengetahui berapa besar prosentase kontribusi harga terhadap minat beli pada PT Asuransi Jiwa Recapital di Jakarta.

\section{ANALISIS DAN PEMBAHASAN \\ Analisis Deskriptif Variabel Penelitian}

Sesuai dengan tujuan analisis deskriptif yaitu untuk memberikan gambaran mengenai hasil penelitian secara umum, bagaimana karakteristik subyek penelitian sehubungan dengan variabel-variabel yang diteliti. Sebelum dilakukan analisis statistik terlebih dahulu dila- kukan pembobotan terhadap skor masing-masing variabel. Pembobotan dilakukan dengan memberikan skor total dengan jumlah item dari variabel yang dibobot, melalui pertanyaaan yang diberikan penulis dalam kuesioner dapat di deskriptifkan setiap variabel yang diteliti. Metode yang diambil dalam penelitian ini adalah metode pengukuran Likert. Dimana pertanyaan mengandung lima alternatif jawaban. Dan bentuk pertanyaan telah disusun menggunakan pengukuran Likert yang diberi bobot sebagai berikut:

\section{Variabel Harga (X)}

Harga dalam penelitian ini merupakan bentuk persepsi konsumen dari barang atau produk. Harga merupakan sejumlah uang yang ditukarkan dengan melihat manfaat produk yang nilainya ditetapkan pembeli dan penjual dan diukur melalui indikator :
a. Tingkat harga
b. keringakan harga
c. syarat pembayaran

Adapun penilaian responden atas harga pada PT Asuransi Jiwa Recapital Jakarta dapat dipaparkan sebagai berikut:

Tabel 1. Skala Likert

\begin{tabular}{|c|c|}
\hline Jawaban & Bobot \\
\hline Sangat Setuju (SS) & 5 \\
\hline Setuju (S) & 4 \\
\hline Kurang Setuju (KS) & 3 \\
\hline Tidak Setuju (TS) & 2 \\
\hline Sangat Tidak Setuju (STS) & 1 \\
\hline
\end{tabular}

Sumber: Sugiyono (2014)

Range Kelas

$$
\mathrm{P}=\frac{\text { Range }}{\text { Kelas }}=\frac{5-1}{5}=0,8
$$


Maka dapat ditetapkan interval sebagai berikut :

Tabel 2. Kriteria Rentang Skala

\begin{tabular}{|c|c|}
\hline Nilai Rata-rata & Bobot \\
\hline $1,00-1,79$ & Sangat Tidak Setuju (STS) \\
\hline $1,80-2,59$ & Tidak Setuju (TS) \\
\hline $2,60-3,39$ & Kurang Setuju (KS) \\
\hline $3,40-4,19$ & Setuju (S) \\
\hline $4,20-5,00$ & Sangat Setuju (SS) \\
\hline
\end{tabular}

Sumber: Sugiyono (2014)

Tabel 3. Penilaian Responden Berdasar pada Pertanyaan Variabel Harga

\begin{tabular}{|c|c|c|c|c|c|c|c|c|c|}
\hline No & Pernyataan & STS & TS & KS & S & SS & Total & Rata- & Ket. \\
\hline & & & & (3) & (4) & & & & \\
\hline 1. & $\begin{array}{l}\text { Tarif premi } \\
\text { sesuai } \\
\text { kualitas }\end{array}$ & 1 & 5 & 23 & 46 & 25 & 100 & 3,89 & S \\
\hline 2. & $\begin{array}{l}\text { Tarif premi } \\
\text { sesuai } \\
\text { manfaat }\end{array}$ & 1 & 4 & 18 & 50 & 27 & 100 & 3,89 & S \\
\hline 3. & $\begin{array}{l}\text { Tarif premi } \\
\text { sesuai } \\
\text { produk }\end{array}$ & 1 & 5 & 13 & 48 & 33 & 100 & 4,07 & S \\
\hline 4. & $\begin{array}{l}\text { Tidak } \\
\text { dikenakan } \\
\text { biaya claim }\end{array}$ & 1 & 5 & 22 & 44 & 28 & 100 & 3,93 & S \\
\hline 5. & $\begin{array}{l}\text { Syarat } \\
\text { pembayaran } \\
\text { mudah }\end{array}$ & 2 & 5 & 35 & 42 & 16 & 100 & 3,65 & S \\
\hline 6. & $\begin{array}{l}\text { Syarat } \\
\text { pembayaran } \\
\text { tidak sulit }\end{array}$ & 3 & 5 & 34 & 44 & 14 & 100 & 3,61 & S \\
\hline 7. & $\begin{array}{l}\text { Prosedur } \\
\text { pembayaran } \\
\text { mudah }\end{array}$ & 1 & 1 & 22 & 44 & 32 & 100 & 4,05 & S \\
\hline 8. & $\begin{array}{l}\text { Pembayaran } \\
\text { dapat } \\
\text { diakses }\end{array}$ & 1 & 2 & 17 & 49 & 31 & 100 & 4,07 & $\mathrm{~S}$ \\
\hline & \multicolumn{7}{|c|}{ Rata-rata Variabel Harga } & 3,91 & $\mathbf{S}$ \\
\hline
\end{tabular}

Sumber : Hasil Pengolahan Data Primer

Bila dilihat dari tabel diatas rata-rata skor variabel harga sebesar 3,91 masuk pada interval 3,40 - 4,19 atau dengan interpretasi setuju yang artinya responden mempunyai persepsi bahwa harga yang ditawarkan PT Asuransi Jiwa Recapital terjangkau, bersaing, kompetitif dan memiliki sistem pembayaran yang mudah dan tidak memberatkan pelanggan.

\section{Variabel Minat Beli (Y)}

Minat Beli dalam penelitian ini merupakan keinginan dari pelanggan untuk melakukan pembelian atas produk yang dihasilkan oleh perusahaan sebagai akibat dari adanya rancangan (stimulus) yang ditawarkan oleh perusahaan yang dirancang untuk menghasilkan tindakan pembelian konsumen. Variabel ini diukur melalui indikator : Minat Transaksional, Minat Refrensial, Minat Preferensional dan Minat Eksploratif. Adapun penilaian responden atas produksi yang dilaksanakan pada PT Asuransi Jiwa Recapital dapat dipaparkan sebagai berikut:

\begin{tabular}{|c|c|c|c|c|c|c|c|c|c|}
\hline \multirow[t]{2}{*}{ No } & \multirow[t]{2}{*}{ Pernyataan } & & TS & KS & $\mathbf{S}$ & SS & \multirow[t]{2}{*}{ Total } & \multirow{2}{*}{$\begin{array}{l}\text { Rata- } \\
\text { rata }\end{array}$} & \multirow[t]{2}{*}{ Ket. } \\
\hline & & (1) & (2) & (3) & (4) & (5) & & & \\
\hline 1. & Variasi produk & 1 & 2 & 19 & 44 & 34 & 100 & 4,08 & $\mathrm{~S}$ \\
\hline 2. & $\begin{array}{l}\text { Promosi tidak } \\
\text { membohongi }\end{array}$ & 1 & 5 & 33 & 36 & 25 & 100 & 3,79 & $\mathrm{~S}$ \\
\hline 3. & $\begin{array}{l}\text { Harga premi } \\
\text { terjangkau }\end{array}$ & 1 & 3 & 20 & 41 & 35 & 100 & 4,06 & $\mathrm{~S}$ \\
\hline 4. & $\begin{array}{l}\text { Penuh } \\
\text { Pertimbangan }\end{array}$ & 1 & 3 & 17 & 46 & 33 & 100 & 4,07 & $\mathrm{~S}$ \\
\hline 5. & $\begin{array}{l}\text { Membutuhkan } \\
\text { Produk }\end{array}$ & 1 & 2 & 26 & 40 & 31 & 100 & 3,98 & S \\
\hline 6. & $\begin{array}{l}\text { Melakukan } \\
\text { pembelian }\end{array}$ & 1 & 1 & 22 & 44 & 32 & 100 & 4,05 & $S$ \\
\hline 7. & $\begin{array}{l}\text { Kecermatan } \\
\text { pembelian }\end{array}$ & 2 & 2 & 17 & 55 & 24 & 100 & 3,97 & $S$ \\
\hline 8. & $\begin{array}{l}\text { Kepercayaan } \\
\text { produk }\end{array}$ & 1 & 1 & 18 & 52 & 28 & 100 & 4,05 & S \\
\hline & Rata-r & ata $\mathbf{V}_{\mathbf{c}}$ & arial & el M & nat $B$ & & & 4,01 & $\mathbf{S}$ \\
\hline
\end{tabular}

Sumber : Hasil Pengolahan Data Primer

Bila dilihat dari tabel di atas rata-rata skor variabel produk sebesar 4,01 masuk pada interval 3,40 - 4,19 atau dengan interpretasi setuju yang artinya responden mempunyai persepsi bahwa perusahaan perlu meningkatkan lagi komitmen pembelian sesuai dengan kebutuhan yang diinginkan oleh customer.

\section{PENGUJIAN INSTRUMEN}

1. Hasil Uji Valiiditas

\section{a. Uji Validitas Variabel Harga}

Pengujian validitas digunakan untuk mengetahui kelayakan dari setiap butir pertanyaan dalam penelitian, apakah valid atau tidak valid pernyataan pada pada kuesioner yang digunakan. Dalam uji validitas, peneliti menggunakan ketentuan 
membandingkan antara nilai $r$ hitung dengan nilai $r$ tabel.

Berdasarkan perhitungan yang diolah dengan menggunakan Software IBM SPSS (Statistical Program for Social Science) versi 22.00 for windows, diperoleh nilai rata-rata $r$ hitung sebesar 0,436 dimana nilai tersebut lebih besar dari 0,197 ( $r$ hitung $>r$ tabel), dengan demikian seluruh butir pernyataan yang digunakan dalam penelitian dinyatakan Valid.

\section{b. Uji Validitas Variabel Minat Beli}

Berdasarkan perhitungan yang diolah dengan menggunakan Software IBM SPSS (Statistical Program for Social Science) versi 22.00 for windows, untuk variabel minat beli diperoleh nilai rata-rata $r$ hitung sebesar 0,541 dimana nilai tersebut lebih besar dari 0,197 ( $\mathrm{r}$ hitung $>$ r tabel), dengan demikian seluruh butir pernyataan yang digunakan dalam penelitian dinyatakan Valid.

\section{Hasil Uji Reliabilitas}

\section{a. Uji Reliabilitas Variabel Harga}

Pengujian reabilitas dimaksudkan untuk menguji suatu kuesioner yang dipergunakan konsisten atau stabil atau tidak. Adapun kriteria untuk mengolah uji reliabilitas. Dalam uji reliabilitas ini peneliti menggunakan ketentuan membandingkan antara nilai $r$ hitung dengan nilai $r$ tabel.

Berdasarkan perhitungan yang diolah dengan menggunakan Software IBM SPSS (Statistical Program for Social Science) versi 22.00 for windows, untuk penyataan variabel harga diperoleh nilai rata-rata $r$ hitung sebesar 0,344 dimana nilai tersebut lebih besar dari 0,197 ( $r$ hitung $>r$ tabel), dengan demikian seluruh butir pernyataan yang digunakan dalam penelitian dinyatakan Reliabel.

\section{b. Uji Reliabilitas Variabel Minat Beli}

Berdasarkan perhitungan yang diolah dengan menggunakan Software IBM SPSS
(Statistical Program for Social Science) versi 22.00 for windows, untuk penyataan variabel minat beli diperoleh nilai rata-rata $r$ hitung sebesar 0,613 dimana nilai tersebut lebih besar dari 0,197 ( $\mathrm{r}$ hitung $>\mathrm{r}$ tabel), dengan demikian seluruh butir pernyataan yang digunakan dalam penelitian dinyatakan Reliabel.

\section{HASIL ANALISIS DATA}

Pada analisis data ini dimaksudkan untuk menunjukkan hasil dari pengujian atas variabel Harga terhadap Minat Beli. Adapun hasil analisis data dalam penelitian ini sebagai berikut:

\section{Analisis Regresi Linier Sederhana}

Berdasarkan perhitungan regresi linier sederhana menggunakan program IBM SPSS (Statistical Program for Social Science) versi 22.00 for windows, diperoleh hasil sebagai berikut :

Tabel 5. Hasil Uji Regresi Linier Sederhana

Coefficients $^{\mathrm{a}}$

\begin{tabular}{|l|c|l|l|l|l|}
\multirow{2}{*}{ Model } & \multicolumn{2}{|c|}{$\begin{array}{c}\text { Unstandardized } \\
\text { Coefficients }\end{array}$} & $\begin{array}{c}\text { Standardized } \\
\text { Coefficients }\end{array}$ & \multirow{2}{*}{ t } & \multirow{2}{*}{ Sig. } \\
\cline { 2 - 6 } & B & Std. Error & Beta & & \\
\hline 1 (Constant) & 10.673 & 3.192 & & 3.344 & .001 \\
\hline Harga $(X)$ & .684 & .102 & .562 & 6.727 & .000 \\
\hline
\end{tabular}

Berdasarkan hasil perhitungan pada tabel di atas dapat disajikan ke dalam bentuk persamaan regresi linier sederhana sebagai berikut : $\mathrm{Y}=10,673+0,684$

Di mana :

$\mathrm{Y}=$ Minat Beli

$\mathrm{X}=$ Variabel Harga

Adapun persamaan tersebut dapat dijelaskan sebagai berikut :

Konstanta sebesar 10,673, menyatakan bahwa tanpa dipengaruhi oleh variabel harga, maka besarnya nilai minat beli sudah terbentuk sebesar 0,684 .

Variabel harga $(\mathrm{X})$ berpengaruh positif terhadap minat beli $(\mathrm{Y})$ dengan nilai koefisien sebesar 0,684. Yang artinya jika variabel har- 
ga (X) meningkat satu satuan, maka minat beli akan mengalami peningkatan sebesar 0,684 satuan.

\section{Analisis Koefisien Korelasi}

Analisis Koefisien Korelasi dimaksudkan untuk mengetahui tingkat hubungan antara variabel harga terhadap minat beli, dapat dijelaskan sebagai berikut :

Tabel 6. Hasil Pengujian Koefisien Determinasi

Model Summary

\begin{tabular}{|l|l|r|r|r|}
\hline Model & \multicolumn{1}{|c|}{ R } & R Square & $\begin{array}{c}\text { Adjusted R } \\
\text { Square }\end{array}$ & $\begin{array}{l}\text { Std. Error of } \\
\text { the Estimate }\end{array}$ \\
\hline 1 & $.562^{\mathrm{a}}$ & .316 & .309 & 3.011 \\
\hline
\end{tabular}

Sumber: Hasil Pengolahan Data Primer

Dari tabel di atas dapat dilihat bahwa nilai Koefisien Korelasi $(R)$ adalah sebesar 0,562. Hal ini menunjukkan bahwa variabel harga memiliki tingkat hubungan atau pengaruh yang sedang terhadap minat beli.

\section{Analisis Koefisien Determinasi}

Untuk mengetahui kontribusi besarnya pengaruh variabel harga terhadap minat beli, dapat dijelaskan sebagai berikut :

\section{Tabel 7. Hasil Pengujian Koefisien Determinasi Model Summary}

\begin{tabular}{|l|r|r|r|r|}
\hline Model & R & R Square & $\begin{array}{l}\text { Adjusted } \\
\text { R Square }\end{array}$ & $\begin{array}{l}\text { Std. Error of } \\
\text { the Estimate }\end{array}$ \\
\hline 1 & $.562^{\mathrm{a}}$ & .316 & .309 & 3.011 \\
\hline
\end{tabular}

Sumber: Hasil Pengolahan Data Primer

Dari tabel di atas dapat dilihat bahwa nilai $R$ Square sebesar 0,316 atau $31,6 \%$. Hal ini menunjukkan bahwa pengaruh harga terhadap minat beli sebesar $31,6 \%$. Sisanya sebesar $68,4 \%$ dipengaruhi oleh faktor lain yang tidak diteliti.

\section{Pengujian Hipotesis}

Untuk menguji pengaruh variabel harga (X) terhadap minat beli (Y) digunakan uji t dengan rumusan hipotesis sebagai berikut:
$\mathrm{H}_{0}: \rho=0$ tidak terdapat pengaruh yang signifikan antara harga $(X)$ terhadap minat beli $(Y)$.

$H_{1}: \rho \neq 0$ terdapat pengaruh yang signifikan harga $(X)$ terhadap minat beli $(Y)$.

Adapun kriteria pengujiannya ;

Terdapat pengaruh yang signifikan bila $t$ hitung $>\mathrm{t}$ tabel

Sedangkan pengujian hipotesis dilakukan dengan membandingkan antara nilai t hitung > $\mathrm{t}$ tabel dengan kriteria penolakan dan penerimaan hipotesis Ho adalah sebagai berikut:

a. Jika t hitung $<\mathrm{t}$ tabel, maka H0 diterima dan H1 ditolak.

b. Jika t hitung $>\mathrm{t}$ tabel, maka H0 ditolak dan H1 diterima.

Adapun hasil pengujian hipotesis adalah sebagai berikut:

Tabel 8. Hasil Pengujian Hipotesis

\begin{tabular}{|c|r|r|r|r|r|}
\hline \multirow{2}{*}{ Model } & \multicolumn{2}{|c|}{$\begin{array}{c}\text { Unstandardized } \\
\text { Coefficients }\end{array}$} & $\begin{array}{c}\text { Standardized } \\
\text { Coefficients }\end{array}$ & t & Sig. \\
& \multicolumn{1}{|c|}{ B } & Std. Error & Beta & & \\
\hline 1 (Constant) & 10.673 & 3.192 & & 3.344 & .001 \\
Harga (X) & .684 & .102 & .562 & 6.727 & .000 \\
\hline
\end{tabular}

Sumber : Hasil Pengolahan Data Primer

Berdasarkan tabel di atas, diperoleh t hitung lebih besar dari t tabel atau $(6,727>1,984)$, hal itu juga diperkuat dengan signifikansi 0,000 $<0,05$, dengan demikian $\mathrm{H} 0$ ditolak dan $\mathrm{H} 1$ diterima. Artinya terdapat pengaruh positif dan signifikan antara harga terhadap minat beli pada PT Asuransi Jiwa Recapital di Jakarta.

\section{PEMBAHASAN DAN HASIL}

Dari hasil pengujian statistik dan analisis diatas, maka dapat dipaparkan analisis pengaruh harga terhadap minat beli pada PT Asuransi Jiwa Recapital di Jakarta, sebagai berikut :

Pengaruh Harga Terhadap Minat Beli Pada PT Asuransi Jiwa Recapital di Jakarta.

․ Korelasi antara harga dan minat beli adalah 0,562 . Dapat dikatakan bahwa adanya hubungan positif sebesar 0,562 antara variabel harga dengan minat beli Pada PT Asuransi Jiwa Recapital di Jakarta.

口 Model regresi yang diperoleh adalah $\mathrm{Y}=$ $10,673+0,684$ 
ㅁ Nilai Rsquare 0,316 , data tersebut mengindikasikan bahwa harga memberikan kontribusi sebesar 31,6\% terhadap minat beli pada PT Asuransi Jiwa Recapital di Jakarta.

$\square$ Nilai thitung sebesar 6,727 dengan signifikansi t sebesar 0,000

$\square \quad$ Nilai ttabel $(0,05 ; 98)=1,984$

$\square$ Karena thitung $>$ ttabel $(6,727>1,984)$ dan signifikansi $t<0,05(0,000<0,05)$

Berarti Hipotesis $\mathrm{H} 1$ yang penulis ajukan dapat diterima.

Hal ini menunjukkan bahwa harga berpengaruh positif dan siginifikan terhadap minat beli pada PT Asuransi Jiwa Recapital di Jakarta.

\section{KESIMPULAN, IMPLIKASI DAN SARAN \\ Kesimpulan}

Setelah penulis melakukan penelitian dan analisis mengenai pengaruh harga terhadap minat beli pada PT Asuransi Jiwa Recapital di Jakarta, seperti yang telah dipaparkan pada babbab sebelumnya, maka penulis dapat menarik kesimpulan sebagai berikut :

1. Kondisi variabel harga dari jumlah 8 pernyataan yang diajukan, tanggapan responden beragam, responden yang menjawab baik, dan sangat baik sebesar $(45,9 \%+25,8 \%=$ $71,7 \%)$, sedangkan yang menjawab kurang baik, tidak baik dan sangat tidak baik sebesar $(23 \%+4 \%+1,4 \%=28,4 \%)$. Meskipun rata-rata skor diperoleh 3.91 dimana nilai tersebut termasuk pada rentang skala 3,404,19 dengan kriteria baik, namun mengingat jumlah responden yang menjawab kurang baik, tidak baik dan sangat tidak baik mencapai 28,4\% maka untuk lebih baik lagi perusahaan perlu mempertimbangkan kebijakan harga agar dapat kompetitif lagi dibandingkan dengan harga yang dikeluarkan oleh competitor, dan PT Asuransi Jiwa Recapital harus menetapkan harga dengan lebih melihat dari apa yang kita hasilkan.

2. Kondisi variabel minat beli dari jumlah 8 pernyataan yang diajukan, tanggapan responden beragam, responden yang men- jawab baik, dan sangat baik sebesar (44,8\% $+30,3 \%=75,1 \%)$, sedangkan yang menjawab kurang baik, tidak baik dan sangat tidak baik sebesar $(21,5 \%+2,4 \%+1,1 \%=$ $24,9 \%)$. Meskipun rata-rata skor diperoleh 4.01 dimana nilai tersebut termasuk pada rentang skala 3,40-4,19 dengan kriteria baik, namun mengingat jumlah responden yang menjawab kurang baik, tidak baik dan sangat tidak baik mencapai $24,9 \%$ maka untuk lebih baik lagi maka perusahaan perlu meningkatkan memberikan perlindungan yang maksimal atas kondisi pelanggan dengan memberikan tambahan asuransi yang lebih komprehensif dalam bentuk reimbursement maupun cashless serta dukungan dengan jaringan rumah sakit yang lebih banyak.

3. Harga berpengaruh positif dan siginifikan terhadap minat beli pada PT Asuransi Jiwa Recapital di Jakarta. Hal ini dapat dilihat dari Nilai thitung $>$ ttabel $(6,727>1,984)$ dan signifikansi $t<0,05(0,000<0,05)$ harga mempunyai korelasi positif dengan minat beli sebesar 0,562. Harga mempunyai kontribusi pengaruh sebesar $31,6 \%$ terhadap minat beli. Model regresi sederhana yang diperoleh adalah $\mathrm{Y}=10,673+0,684$.

\section{Implikasi}

Dari hasil kesimpulan di atas, penelitian ini memiliki implikasi sebagai berikut :

1. Agar tingkat minat beli pada PT Asuransi Jiwa Recapital di Jakarta tetap tinggi sesuai dengan harapan perusahaan maka hendaknya variabel harga harus diperhatikan dan disesuaikan dengan daya beli konsumen, indikator-indikator yang ada dalam harga mengingat harga merupakan satu-satunya bauran pemasaran yang terkait dengan uang maka diharapkan dalam menetapan harga harus dilakukan dengan tepat agar bisa bersaing dengan perusahaan asuransi lain karena jika tidak tepat maka dapat mengakibatkan adanya penurunan hasil penjualan. 
2. Agar tingkat minat beli pada PT Asuransi Jiwa Recapital di Jakarta tetap tinggi maka hendaknya perusahaan juga mempertimbangkan untuk memperbaiki kondisi variabel lainnya secara terintegrasi dan ditingkatkan serta dipahami oleh pihak PT Asuransi Jiwa Recapital, guna mendukung terciptanya proses pembelian konsumen yang berkelanjutan. Perusahaan juga harus dapat menerapkan strategi pemasaran yang lain secara komprehensif dan menciptakan sebuah kinerja perusahaan yang mencapai pada kepuasan pelanggan, yang pada akhirnya akan meningkatkan hasil penjualan perusahaan.

\section{Saran}

Berdasarkan kesimpulan di atas, maka penulis mengajukan beberapa saran yang diharapkan dapat bermanfaat bagi PT Asuransi Jiwa Recapital. Adapun saran tersebut adalah sebagai berikut:

1. PT Asuransi Jiwa Recapital harus meningkatkan usaha-usaha yang berkaitan dengan variabel harga, misalnya perusahaan harus bisa menetapkan harga yang kompetitif karena harga yang sekarang ada belum bisa bersaing dengan kompetitor dan perusahaan harus memiliki sistem pembayaran yang mudah dan tidak memberatkan pelanggan, dengan begitu pelanggan akan memilih asuransi kita.

2. PT Asuransi Jiwa Recapital harus meningkatkan usaha-usaha yang berkaitan dengan variabel minat beli, perusahaan perlu meningkatkan lagi komitmen pembeli sesuai dengan kebutuhan yang diinginkan oleh customer, perlu meningkatkan perkembangan dari masa dahulu sampai sekarang agar mudah mempengaruhi perilaku para pelanggan dalam pembelian produk.

\section{DAFTAR PUSTAKA}

Appley A,Lawrence, Lee,Oey,Liang. 2010. Pengantar Manajemen. Salemba Empat. Jakarta.

Arief S. Sadiman, dkk. 2011. "Media Pendidikan, Pengertian, Pengembangan, dan Peman- faatannya". Rajawali Press. Jakarta.

Arikunto, Suharsimi. 2010. Prosedur Penelitian Suatu pendekatan Praktek. Jakarta: Rineka Cipta.

Augusty, Ferdinand. 2006. Metode Penelitian Manajemen: Pedoman Penelitian untuk Skripsi, Tesis dan Disertasi Ilmu Manajemen, Badan Penerbit Universitas Diponegoro. Semarang.

Babin, Zikmund, 2011."Menjelajahi Riset Pemasaran. Edisi Kesepuluh. Penerbit Salemba empat. Jakarta.

Buchari Alma. 2011. Manajemen Pemasaran dan Pemasaran Jasa. Penerbit Alfabeta. Bandung.

G.R. Terry. 2010. Manajemen Sumber Daya Manusia. Edisi Pertama. Cetakan Pertama. Kencana. Jakarta.

Hasibuan, Malayu. 2013. "Manajemen Sumber Daya Manusia”. Cetakan ke tujuh belas. Bumi Aksara. Jakarta.

Hurriyati Ratih, Dr., M.Si. "Bauran Pemasaran dan Loyalitas Konsumen”. 2010. Alfabeta CV. Jakarta.

Keller dan Amstrong, 2012. "Prinsip-prinsip Pemasaran”, Edisi Kedua Belas, Jilid Satu, Erlangga, Jakarta.

Kinnear, Thomas C. and James R. Taylor, 2011. Marketing Research: An Applied Approach. McGraw Hill Text.

Kotler, Philip dan Gary Armstrong, 2012. Principles Of Marketing, Edisi 14, New Jersey: Prentice-Hall Published.

Kotler, Philip, 2012."Manajemen Pemasaran", Edisi Keempat belas, PT. Indeks, Jakarta.

Kotler, Philip. dan Kevin Lane Keller, 2012." Manajemen Pemasaran", PT Macaman Jaya Cemerlang, Jakarta.

Mehr \& Cammack - A. Hasyimi. 2013 "Dasardasar Asuransi”, Balai Aksara, Jakarta.

Mowen dan Minor, 2012. Perilaku Konsumen. Jilid I Edisi Kelima. Alih Bahasa: Lina Salim. Penerbit Erlangga. Jakarta.

Ramli, Samsul, 2013. Bacaan Wajib Para Praktisi Pengadaan Barang/Jasa Pemerintah, 
Visimedia; Jakarta.

Saladin, Djaslim, 2012. "Manajemen Pemasaran", Linda Karya, Bandung.

Sarwono, Jonathan, 2012."Metode Penelitian Kuantitatif Dan Kualitatif", Graha Ilmu, Yogyakarta.

Sugiyono, 2014 "Metode Penelitian Kuantitatif Kualitatif dan $R$ \& D", Penerbit CV. Alfabeta, Bandung.

Swastha, Bashu dan T. Handoko, 2005. "Manajemen Pemasaran Moderen”, BPFE, Yogyakarta.

Tjiptono, Fandy. 2009. "Pemasaran Jasa", Edisi Pertama, Bayu Media Publishing, Malang.

Wiliam J. Stanton, 2010. "Prinsip-Prinsip Pemasaran”, Edisi ketujuh, Erlangga, Jakarta.

Farodis, Zian. 2014. Buku Pintar Asuransi. Edisi ke-1. Laksana.Yogjakarta.

Perundangan

Undang-undang Nomor 2 Tahun 1992, tentang asuransi dan pertanggung jawaban perjanjian asuransi Pasal 246 Kitab Undang-undang Hukum Dagang (KUHD) Republik Indonesia 